\title{
Identification of Heavy Oil (Tar Mats) Deposits and Forming Mechanism in the Main Pay of the Zubair Formation in North Rumaila Oil Field, Southern Iraq
}

\author{
Shaymaa Mohammed J. ${ }^{1^{*}, \text { Amna M Handhal }}{ }^{2}$ \\ ${ }^{1,2}$ University of Basrah, Geology Department, Basrah, Iraq
}

*Corresponding Author: Shaymaa Mohammed J., University of Basrah, Geology Department, Basrah, Iraq

\begin{abstract}
Zubair Formation in the giant oil field of North Rumaila in southern Iraq is a good oil reservoir that consists of friable porous sandstone intercalated with thin shale and siltstone layers. The main pay of this reservoir has a thick variable Tar mat (asphaltic) interval near oil-water contact and influences reservoir production and the aquifer support. To delineate Tar mat zones in the reservoir unit of Zubair Formation, different paradigms were followed in this study including description of the cutting and core samples and borehole logs. Numbers of wells were selected to identify the thickness of Tar mat zone in the eastern and western flanks by core and rock cutting samples in addition to the study of borehole logs such as resistivity and nuclear magnetic resonance logs. Asphaltenes are normally dissolved in hydrocarbons in the form of suspension. Then, we study a number of processes can cause these compounds to drop out of suspension at certain zones and the possible mechanisms of Tar mat formation in the considered reservoirs.
\end{abstract}

\section{INTRODUCTION}

Zubair sandstone reservoir has a variable thick Tar mat (asphaltic) interval near oil water contact and has an impact of the aquifer support of the reservoir. Tar mats are defined as zone of solid organic matter filling voids and fractures of rocks that can be laterally continuous and made a potential barrier to flow of fluid (Jacob, 1989). The Tar mat occurs in carbonate and sandstone petroleum reservoirs in many basins throughout the world (Wilhelm's and Larter, 1995).In the Zubair Formation in the Raudhatain oil field of north Kuwait was studied the origin and distribution of Tar mats (Azim et al., 2006), in Kuwait carbonate reservoir was investigated and modeled the Tar mats and their role in understanding oil reserves and recovery economics (Almansour, 2014), and in Saudi Arabia conducted an experimental study for enhancing the recover factor of Tar barrier and understand distribution of Tar mat (Alfayfi et al., 2015).Recently, the compiled wells in the upper sandstone member (main pay) of the Zubair reservoir in the flank parts of the structure did not significantly contribute to oil production due to the presence of Tar mat (specially at the DJ unit) so the aim of this study was to identify the Tar mat zones at these locations using full set of open hole logs, core, and cuttings descriptions in the eastern and western flanks and the possible mechanisms of Tar mat formation.

\section{Geological SETTING}

The area of North Rumaila giant oil filed locates at Basrah Governorate, south of Iraq about $50 \mathrm{~km}$ west of Basrah centre and $32 \mathrm{~km}$ west of Zubair oil field, between $\left(30^{\circ}, 774^{`}-30^{\circ}, 427^{`}\right)$ latitude and $\left(47^{0}, 223^{\circ}-47^{0}, 428^{\circ}\right)$ longitude (Fig. 1).Geologically the study area located in the Mesopotamian zone (subdivided into three zones namely, the Zubair, the Euphrates, and Tigris subzones) these zones locate in the south, west, and northeast of the Mesopotamian zone, respectively. The North Rumaila oil field is located in the Zubair subzone (Jassim\& Goff, 2006). The North Rumaila structure is an asymmetrical elongated anticline trending almost north - south, and the flanks dip is about 3 degree while the western flank was slightly steeper than the eastern side. The dimension of this anticline is 24 $\mathrm{km}$ (length) and $11 \mathrm{~km}$ (width). It plunges gently southward to form a saddle that separates it from the south Rumaila anticline structure (Al-An sari, 1993). Rumaila trap and the structure traps of Iraqi 
Identification of Heavy Oil (Tar Mats) Deposits and Forming Mechanism in the Main Pay of the Zubair Formation in North Rumaila Oil Field, Southern Iraq

southern fields formed by forces that arising from collision of Arabian plate with Iranian plate from the east and Anatolian plate from north during Alpian movement (Al-Sakini, 1992).

Zubair formation was divided into five units to use in reservoir studies, from top to bottom (Owen and Nasser, 1958 in Buday, 1980),(Fig. 2): (1) Upper shale member (shale with two distinct sandstone regions and a slight amount of siltstone) (2) Upper sand member (main pay) (predominating sandstone with subsidiary shale and siltstones) (3) Middle shale member (black or greenish black shale, fissile, hard, with occasional sandstone streaks) (4) Lower sand member(predominating sandstone with subsidiary siltstone beds) (5) Lower shale member (greenish black shale with sandstone - siltstone zone).

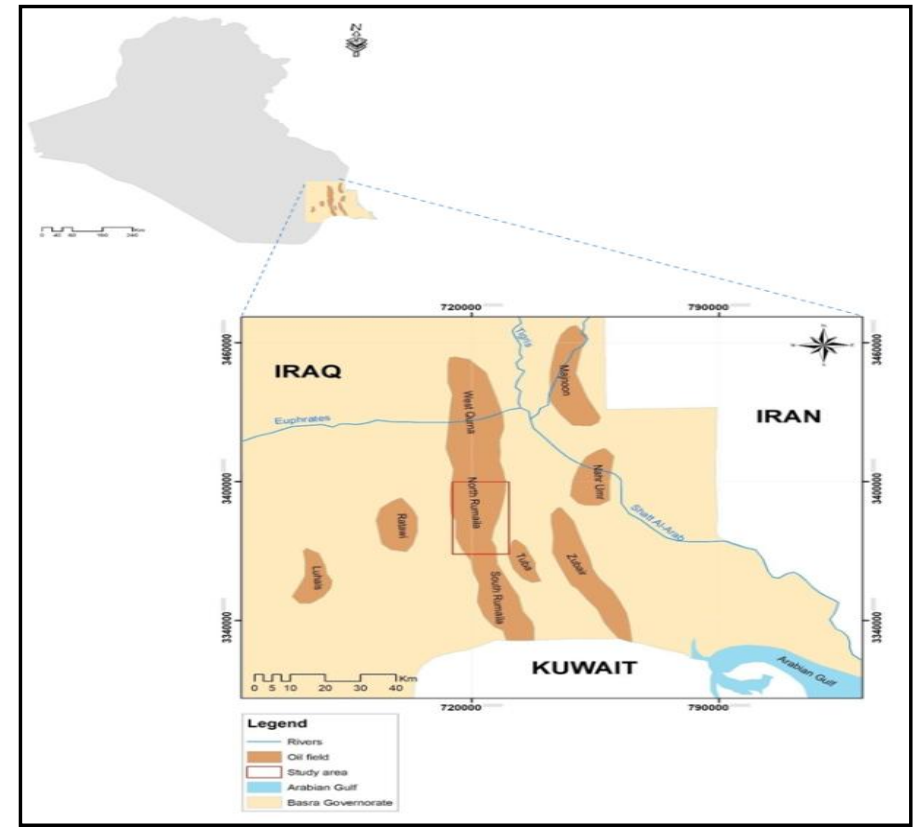

Fig1. Location of the study area

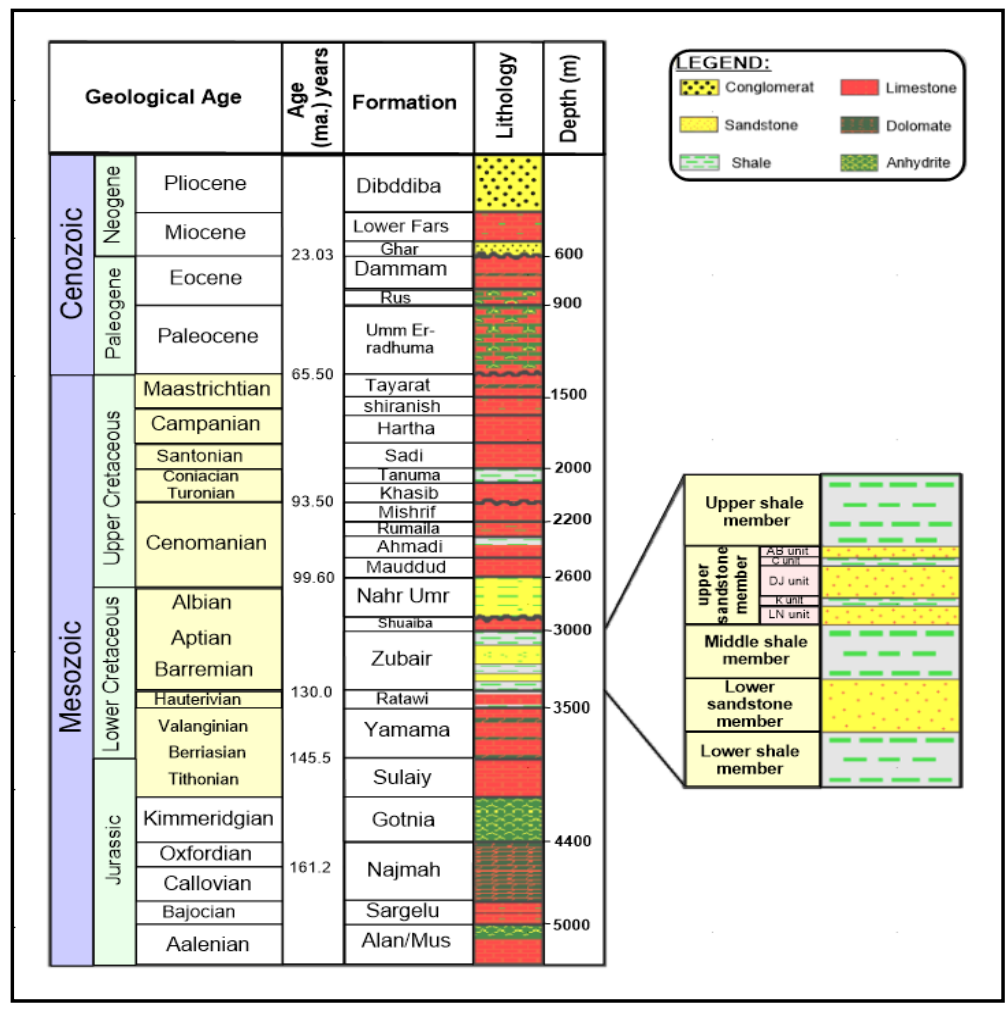

Fig2. Stratigraphic column of Rumailaoil field (Well R-172) 


\section{Material AND MethodS}

Many wells data and samples were selected to determine Tar mat, there are several methods to estimation Tar mat such as core, cutting, micro resistivity logs, bulk volume of mud filtrate in the flashed zone (Bvxo), and Nuclear magnetic resonance (NMR) methods. There is not certain method that can be applied to all wells, and in most cases the interpretation of Tar occurrence is difficult and uncertain due to the fact it can appear in a lot of data sources to be very similar to producible oil. Some methods contain petro physical calculations processed using Techlog software that can be summarized as follows:

1. The specific resistivity of the reservoir rock is the result of two different contributions, the resistivity of the rock matrix and the formation fluid. The electrical properties of the fluid will define the resistivity of the reservoir rock. This value will, therefore, in general depend on porosity, temperature and water salinity (Schlumberger, 1989; 1997). A basic resistivity measurement fluid saturation of reservoir and type of fluid (hydrocarbons, saltwater, or freshwater) depend on behavior of formation resistivity $\left(\mathrm{R}_{\mathrm{t}}\right)$ in uninvaded zone which are recorded actual type of fluid in the formation (hydrocarbons, or formation water), and micro resistivity $\left(\mathrm{R}_{\mathrm{xo}}\right)$ in invaded zone which are recorded resistivity of mud filtrate in flushed zone (Asquith and Krygowski, 2004). Due to Tar mat has very low mobility due to the high viscosity so that resistivity logs are consider as the main wire line devices that can be used for characterizing this type of hydrocarbon in reservoirs. However in front of Tar mat zones the separation between $\mathrm{R}_{\mathrm{xo}}$ and $\mathrm{R}_{\mathrm{t}}$ curves is small if it compared with oil containing zones. This is because there is no mud infiltrate invasion against these zones as Tar mat causes considerable reducing in permeability; the $\mathrm{R}_{\mathrm{xo}}$ reads Tar mat resistivity instead of mud resistivity.

2. The flushed zone is a part of the invaded zone extends a few inches from the borehole. In this zone, the resistivity log measures the resistivity of mud filtrate because this zone completely cleared by mud filtrate. Water saturation in the flushed $\left(S_{\mathrm{xo}}\right)$ can be determined by the degree of flushing of mud filtrate (Asquith and Krygowski, 2004) using Indonesia's equation in the flashed zone is as follows (Poupon and Leveaux, 1971):

$S_{x o}=\left(\frac{V_{S h}^{1-\left(V_{S h} h^{* 0.5}\right.}}{\left(\frac{R_{S h}}{R_{x o}}\right)^{0.5}}+\left(\frac{R_{x o}}{\frac{a * R_{m f}}{\phi^{m}}}\right)^{0.5}\right)^{\frac{-2}{n}}$

Where:

$R_{m f}=$ mud filtrate resistivity (ohm.m)

$a=$ tortuosity factor

$m=$ cementation exponent

$\varnothing=$ porosity $(\%)$

$n=$ Saturation exponent

$S_{x o}=$ flushed saturation $(\mathrm{v} / \mathrm{v})$

$V_{S h}=$ shale volume $(\mathrm{v} / \mathrm{v})$

$R_{x o}=$ flushed zone resistivity (ohm.m)

$R_{s h}=$ shale resistivity (ohm.m)

The corrected resistivity of the mud filtrate $\left(\mathrm{R}_{\mathrm{mf}}\right)$ at formation temperature is corrected by Arp's formula as:

$\mathrm{R}_{\mathrm{TF}}=\frac{\mathrm{R}_{\mathrm{mf}}\left(\mathrm{T}_{1}+21.5\right)}{\left(\mathrm{T}_{2}+21.5\right)}$

$R_{T F}=$ resistivity at formation temperature

$R_{m f}=$ resistivity of mud filtrate at surface temperature

$T_{1}=$ surface temperature 
Identification of Heavy Oil (Tar Mats) Deposits and Forming Mechanism in the Main Pay of the Zubair Formation in North Rumaila Oil Field, Southern Iraq

$T_{2}=$ formation temperature

The bulk volume of mud filtrate $\left(B V_{x o}\right)$ is determined via the following equation:

$B V x o=S_{x o} * \emptyset_{e}$

Where $\emptyset_{e}=$ effective porosity (\%) determined using the following equations (Schlumberger, 1997):

$\emptyset_{e}=\frac{\emptyset_{\text {dcorr }}+\emptyset_{\text {ncorr }}}{2} *\left(1-V_{\text {sh }}\right)$

$\emptyset_{\text {dcorr }}=$ Corrected porosity from density $\log (\%)$

$\emptyset_{\text {ncorr }}=$ corrected porosity from neutron $\log (\%)$

3. The NMR tool excites the formation by the pulse of electromagnetic radiation and measures the decay of the magnetization caused by the pulse and analyses it depends on sensitive to hydrogen index (HI). Hydrogen nuclei (protons) behave like a spinning bar magnet. Protons can be viewed as small magnets when disturbed from equilibrium, they presses around the static magnetic field, The build-up of polarizations proceeds with a time constant defined as the longitudinal relaxation time (T1) (Schlumberger, 2006). The NMR tool not only detects hydrogen but also it can provide information on the chemical environment of the hydrogen through analysis of signal decay of relaxation time named as T2- Distribution. It can be used in many applications such as permeability calculations, producibility, capillary pressure, irreducible water saturation, and hydrocarbon type (Kennedy, 2015).NMR measures amplitude is directly proportional to porosity $(\varnothing)$; the relaxation (decay) rate is related to pore sizes, fluid type and viscosity. Short T2 times indicate small pores, while long $\mathrm{T} 2$ times indicate large pores with relatively higher permeability (Schlumberger, 2006).

Total porosity and T2 distribution are very different in the oil leg when compare to the Tar mat horizons depending on the hydrogen index (HI) of fluids in the porous rocks. The HI index will become very low in Tar mat zones in contrast with zone containing medium to light oil (Nascimento andGomes, 2004).The NMR measurements in heavy oil zones will exhibit porosity deficit proportional to the reduced hydrogen index. This porosity deficit, combined with a shorter T2 result from increased viscosity, can be an effective method to identify Tar. The NMR tool is responding directly to the Tar mat, this method is widely regarded as the best to identify an accurate Tar mat from logs. (Kleinberg and Vinegar, 1996; Nascimento and Gomes, 2004).

\section{RESULTS AND DISCUSSION}

\subsection{Identification of Tar Mat}

Core method: is the best to identify Tar filled zones due to the dark coloring of the core when compared to oil or water filled zones, but core is not available everywhere. Therefore, four wells (R019, R-025, R-028, and R-029) were selected that have reliable cores. The Tar mat zones were clearly distinguished through observing the dark color, the thickness of Tar mat zone of these cores, the resulting thickness calculations were tabulated in (Table 1).

Table1. Thickness of Tar mat zones for selected wells

\begin{tabular}{|c|c|c|c|c|c|c|c|}
\hline NO. & $\begin{array}{l}\text { Well } \\
\text { NO. }\end{array}$ & Flank & $\begin{array}{c}\text { Top of } \\
\text { Tar zone } \\
(\mathbf{m})\end{array}$ & $\begin{array}{c}\text { Bottom of } \\
\text { Tar zone } \\
(\mathbf{m})\end{array}$ & $\begin{array}{c}\text { Thickness of } \\
\text { Tar with } \\
\text { shale (m) }\end{array}$ & $\begin{array}{c}\text { Shale thickness } \\
\text { within Tar (m) }\end{array}$ & $\begin{array}{c}\text { Thickness of } \\
\text { Tar without } \\
\text { shale (m) }\end{array}$ \\
\hline 1 & R-019 & East & 3266.5 & 3278.7 & 12.2 & 3 & 9.2 \\
\hline 2 & R-025 & West & 3257.8 & 3268.5 & 10.7 & 2.6 & 8.1 \\
\hline 3 & R-028 & East & 3214.8 & 3230.4 & 15.6 & 3.1 & 12.5 \\
\hline 4 & R-029 & West & 3269.4 & 3277.7 & 8.3 & 0 & 8.3 \\
\hline
\end{tabular}

Cuttings method: can be useful in identifying Tar, as the cuttings should show a dark coloring as seen in the core, especially, if these data combined with gas chromatograph data that can be an effective method to spot Tar provided that the mud logger is sufficiently experienced and capable of indemnifying and interpreting it. The cuttings also require depth calibration with layers and lag time correction for washouts. Cutting samples were gotten from two wells namely; R-576 and R-181, the thickness of tar mat zone of these cores in addition to the shale zones were determined and calibrated 
Identification of Heavy Oil (Tar Mats) Deposits and Forming Mechanism in the Main Pay of the Zubair Formation in North Rumaila Oil Field, Southern Iraq

with Techlog software. The resulting of thickness were $5.2 \mathrm{~m}$ in R-181, and $10 \mathrm{~m}$ in R-567 show fig. 3.

Micro Resistivity Logs method: it can be easily detect the Tar mat occurrence using this method enhancement by the separation between Rxo and Rt curves in front of Tar mat zones is small if it compared with oil containing zones, thus the Tar mat thickness were determined for many wells in both west and east flanks of North Rumaila oil field (Table 2; Figs. 3\& 4).

Bulk volume of mud filtrate in the flashed zone (Bvxo) method: using petro physical calculations were estimation the Tar mat thickness through observation diminution of bulk volume of mud filtrate $\left(\boldsymbol{B} \boldsymbol{V}_{\boldsymbol{x}}\right)$ shown (Track 7 in Figs. 3\& 4).

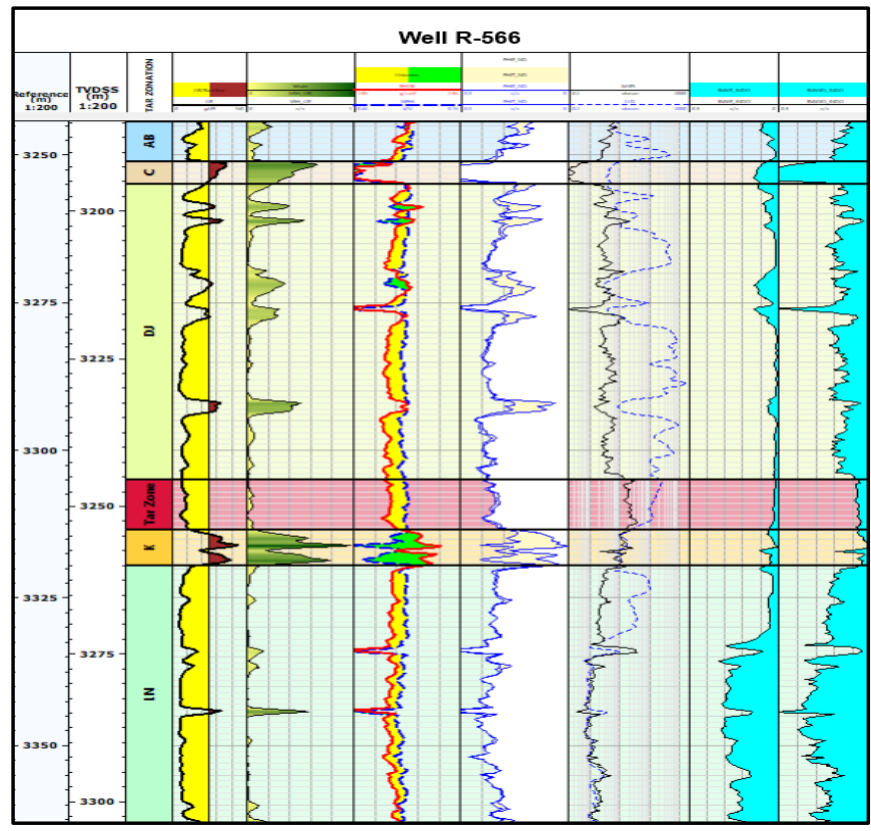

Fig3. Tar mat zone in well $R-566$

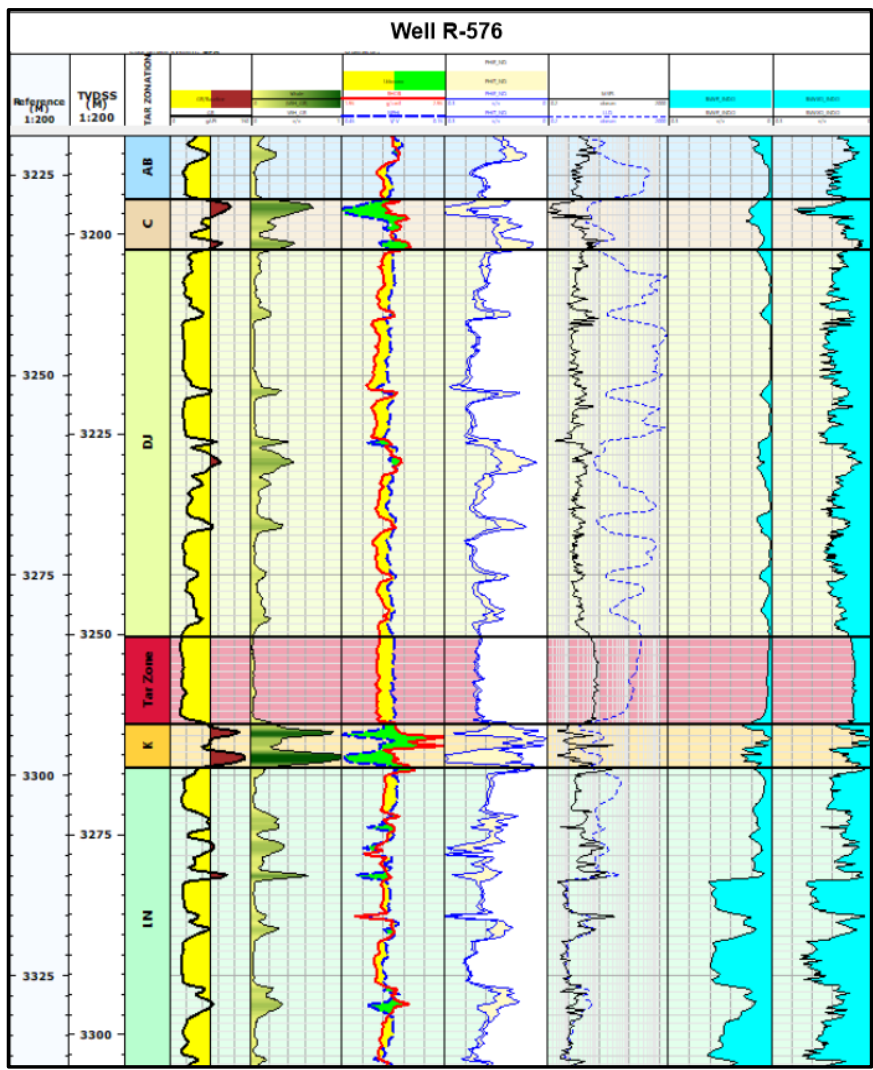

Fig4. Tar mat zone in well $R-576$ 
Identification of Heavy Oil (Tar Mats) Deposits and Forming Mechanism in the Main Pay of the Zubair Formation in North Rumaila Oil Field, Southern Iraq

Table2. Tar thickness using resistivity logs response

\begin{tabular}{|c|c|c|c|c|c|c|c|}
\hline $\begin{array}{l}\mathrm{N} \\
\mathrm{O} .\end{array}$ & Well NO. & Flank & $\begin{array}{c}\text { Top of Tar } \\
\text { zone (m) }\end{array}$ & $\begin{array}{c}\text { Bottom of } \\
\text { Tar zone (m) }\end{array}$ & $\begin{array}{c}\text { Thickness of Tar } \\
\text { with shale }(\mathrm{m})\end{array}$ & $\begin{array}{l}\text { shale thickness } \\
\text { within Tar (m) }\end{array}$ & $\begin{array}{c}\text { Thickness of } \\
\text { Tar without } \\
\text { shale }(\mathrm{m})\end{array}$ \\
\hline 1 & R-139 & East & 3203.8 & 3212 & 8.2 & - & 8.2 \\
\hline 2 & R-028 & East & 3214.8 & 3230.4 & 15.6 & 3.1 & 12.5 \\
\hline 3 & R-108 & East & 3250 & 3262.2 & 12.2 & - & 12.2 \\
\hline 4 & R-019 & East & 3266.5 & 3278.7 & 12.2 & 3 & 9.2 \\
\hline 5 & R-104 & East & 3267.1 & 3278.8 & 11.7 & - & 11.7 \\
\hline 6 & $\mathrm{R}-110$ & East & 3272.6 & 3283.4 & 10.8 & - & 10.8 \\
\hline 7 & R-576 & East & 3282.7 & 3292.7 & 10 & - & 10 \\
\hline 8 & R-594 & East & 3367.7 & 3377.4 & 9.7 & - & 9.7 \\
\hline 9 & R-566 & East & 3305 & 3313.4 & 8.4 & - & 8.4 \\
\hline 10 & R-585 & East & 3280.1 & 3288.1 & 8 & - & 8 \\
\hline 11 & R-101 & West & 3267.2 & 3278.8 & 11.6 & 3 & 8.6 \\
\hline 12 & R-098 & West & 3253 & 3265.2 & 12.2 & 3.6 & 8.6 \\
\hline 13 & R-025 & West & 3257.8 & 3268.5 & 10.7 & 2.6 & 8.1 \\
\hline 14 & R-095 & West & 3256.3 & 3270.5 & 14.2 & 3.3 & 10.9 \\
\hline 15 & R-029 & West & 3269.4 & 3277.7 & 8.3 & - & 8.3 \\
\hline 16 & R-105 & West & 3253.2 & 3258.5 & 5.3 & - & 5.3 \\
\hline 17 & R-023 & West & 3251.2 & 3257.4 & 6.2 & - & 6.2 \\
\hline 18 & R-107 & West & 3274.4 & 3281.7 & 7.3 & - & 7.3 \\
\hline 19 & R-091 & West & 3267.2 & 3273.7 & 6.5 & - & 6.5 \\
\hline 20 & R-127 & West & 3273.4 & 3284 & 10.6 & - & 10.6 \\
\hline
\end{tabular}

Nuclear magnetic resonance (NMR) method: the NMR measurements are available for R-564 well locates in the east flank of the North Rumaila structure. The NMR data were processed in Techlog software (Fig. 2.10). Through observing T2-distribution in the main pay of Zubair Formation, it can be concluded that in the zones saturated with light and medium oil, T2-distribution peaks are to the right of T2-cut off (equals to $33 \mathrm{~ms}$ ). In contrast, in the water saturation zones and Tar mat zones, T2distribution peaks are to the left of T2-cut off. In addition, all peaks to the right of T2-cut off are not sharp and there is a distribution of peaks to the left the depths (3271.3 $\mathrm{m}$ and $3287 \mathrm{~m})$. This may attributed to the occurrence of high viscosity and immovable hydrocarbon (classified as movable Tar). To ensure that this area containing Tar mat, the porosity determined by NMR tool is compared with that estimated from density logs. The porosity from NMR should be less than that estimated form density logs in areas with Tar mat (Track 6). The results also confirmed through calculation of permeability by Timur equation and SDR method. The permeability reduced in Tar areas as shown in Track 7. The final results proved that the Tar mat thickness in R-567 equals to $15.7 \mathrm{~m}$ (from depth 3271.3 to $3287 \mathrm{~m})$.

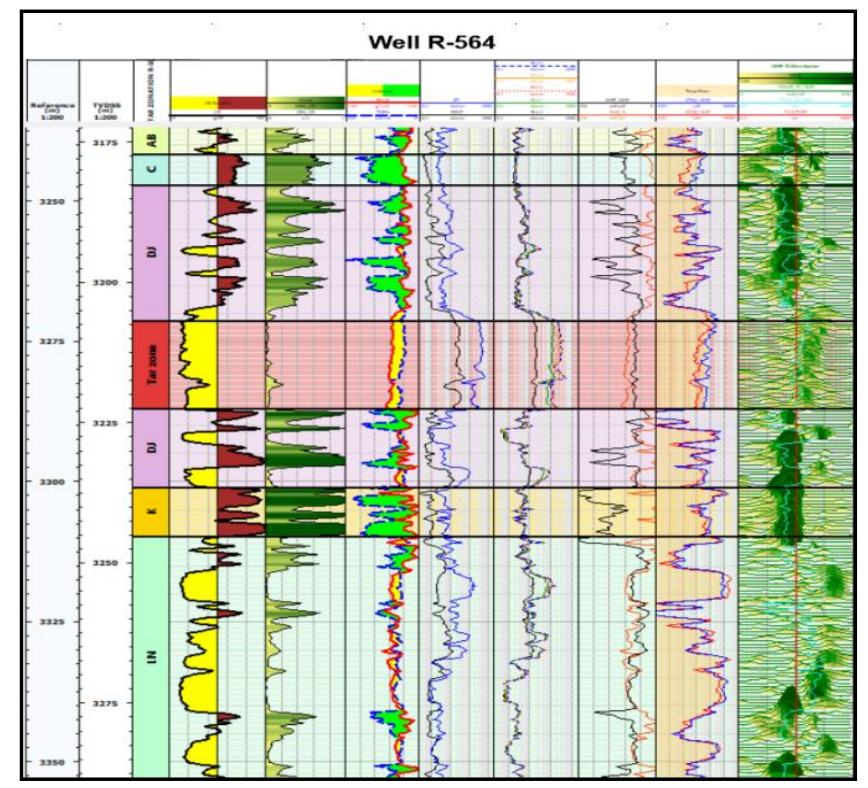

Fig5. Tar mat zone in well $R-564$ 


\subsection{Mechanism of Tar Mat}

There are many processes can cause these compounds to drop out of suspension at certain zones in the form of Tar mats.Mechanisms of Tar mat forming were reviewed by thermal cracking, water washing and biodegradation, deasphaltening by gas charging, gravity segregation, Oil mixing, inreservoir/carrier maturation and reservoir pressure reduction due to uplift (Dahl and Speers, 1985; Wilhelm's and Larter, 1995). In addition, different other mechanisms have been suggested but they are not widely accepted including adsorption of asphaltenes onto clay minerals (Dahl and Speers, 1985) and processes related to thermal convection in oil columns (Montel and Gouel, 1985). Here, we reviewed the possible Tar mat formation mechanisms in the considered reservoir:

Petroleum maturation and thermal cracking: Larter et al., (1990) proposed the maturation of the oil inplace as mechanism for Tar mat formation. On the other hand, Milner et al., (1977) reported that the advanced stages of in- reservoir oil cracking may be responsible for pyrobitumen formation. From (Fig. 6) it can be seen that the Zubair Formation reaches the early oil generation stage at Miocene and the low maturation of the oil at this stage may be responsible for forming the Tar mat. The geochemical analysis of Tar mat samples showed that the origin of oil is marine and from algae sources and thus this evidence exclude the deltaic Zubair Formation as a source to create Tar mat. In addition, if the low maturity is accepted as a mechanism for generating Tar mat, the distribution of Tar mat in the Zubair Formation should be evenly distributed through the whole formation and this is not the case encounter where the Tar mat only concentrates on the flanks of the structure.

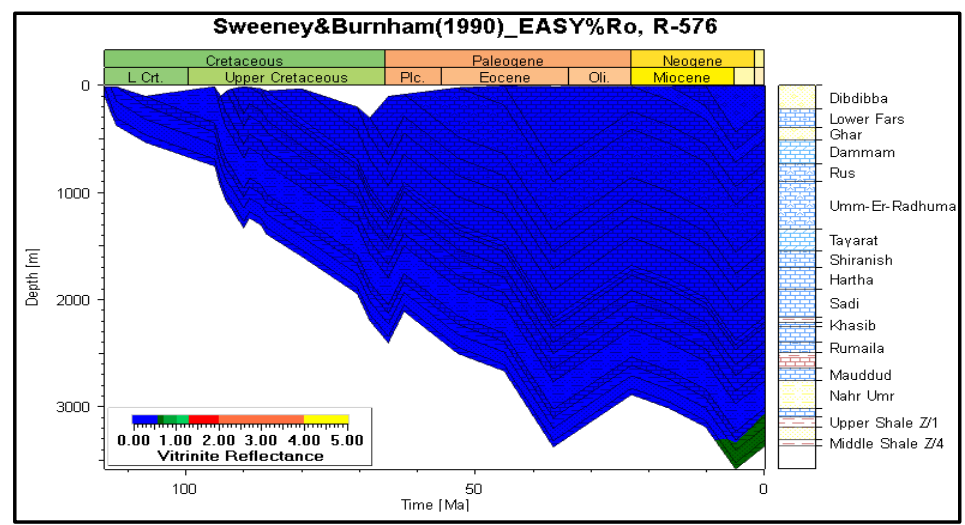

Fig6. History of thermail maturation of Zubair formation in study area.

The thermal cracking is regarded as a mechanism for Tar mat formation in petroleum reservoir which usually occurs at great depth with a geological temperature reaching $170{ }^{\circ} \mathrm{C}$ or higher (Huc et al., 2000; Waples, 2000). As the reservoir temperature of the Zubair formation does not exceed $100^{\circ} \mathrm{C}$, so the thermal cracking mechanism can be ruled out (Fig. 7).

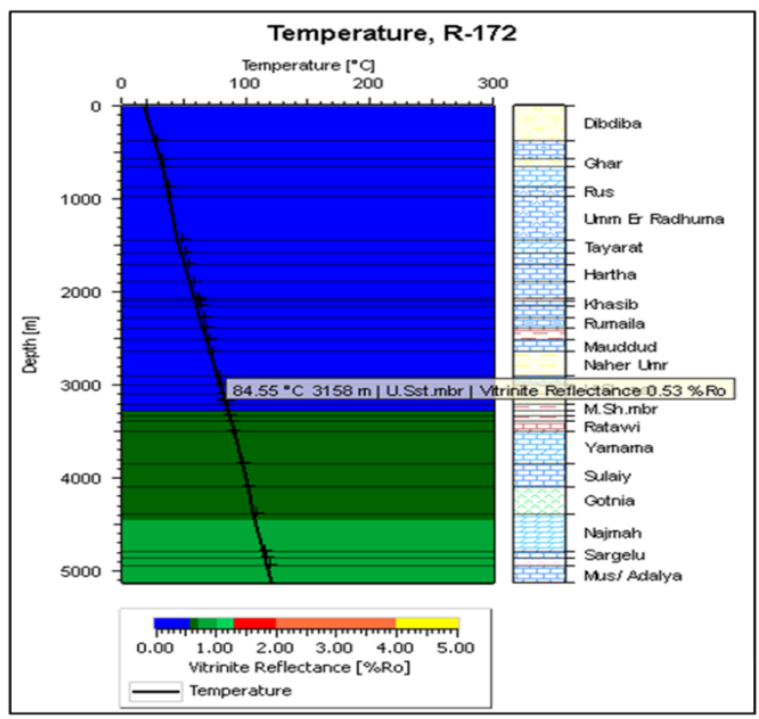

Fig7. Temperature of Zubair formation in well R-172 
Biodegradation: Biodegradation may occur in an oil reservoir accompanied by water washing (Palmer, 1984). This mechanism may be responsible for producing Tar mat due to microbial attack if the process happen near the oil-water contact, the temperature is less than $80^{\circ} \mathrm{C}$ under anaerobic conditions (Head et al., 2003), and removal of n-alkanes with other petroleum components by bacteria (Connan, 1984).

The burial history of the Zubair reservoir indicated that the oil generation and migration history of the source rock begin at upper cretaceous (68 MY), (Fig. 6). At that period, the formation temperature was about $\left(50-53^{\circ} \mathrm{C}\right)$ and this range of temperature creates favourable condition for biodegradation of the trapped oil. At Miocene, the migrated hydrocarbon entered the trap. At the same time the temperature of Zubair formation reached at $71{ }^{0} \mathrm{C}$, a temperature that unfavourable for biodegradation process, (Fig. 8). In this study, geochemical data and temperature exclude biodegradation as possible processes for the formation of the Tar mat in the Zubair sandstone reservoir.

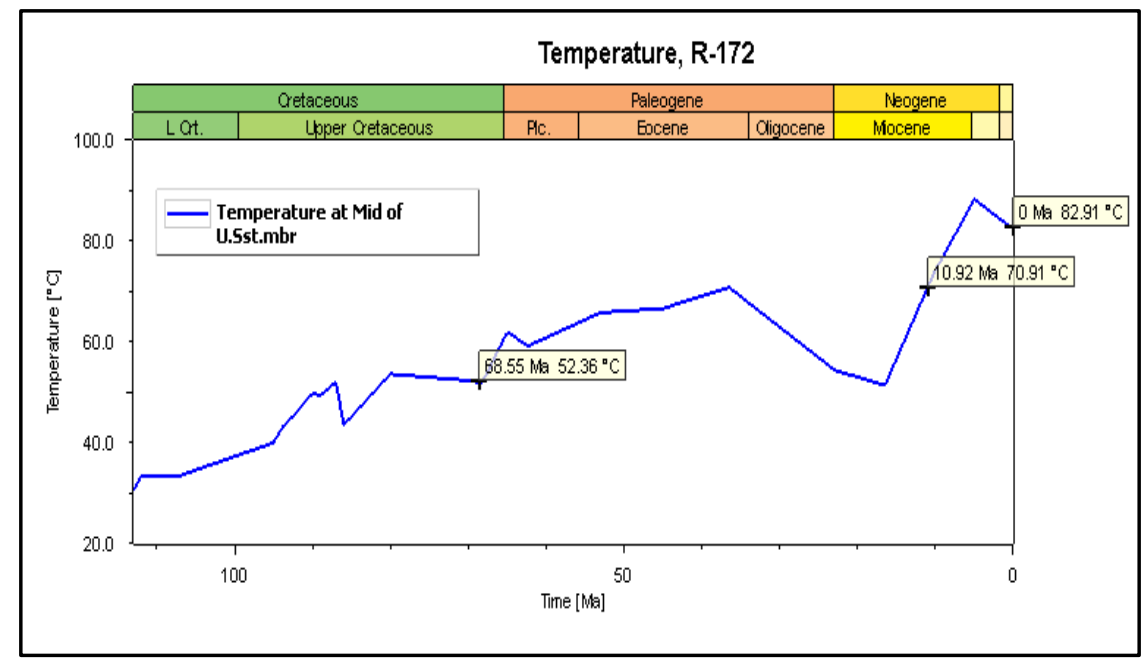

Fig8. Temperature of Zubair formation via time in well $R-172$

Gravity segregation: This mechanism takes place in a reservoir when there is a variation of components that differ in gravity, for example asphltenes in lighter oil. In such cases, the lighter components accumulate near the top of the oil column whereas the denser tend to settle at the base of that column at the oil-water contact. Once the asphaltene content of oil becomes higher than its solubility, the former begin to precipitate and form a Tar mat layer (Schulte, 1980; Hirschberg, 1984). In the Zubair reservoir, the stratigraphic distribution of this mat in the DJ unit (upper unit of the reservoir) should be less spread in LN unit (lower unit of the reservoir). But this is not the case of this reservoir, as the Tar mat more distribute in the DJ unit than the lower unit LN.

De-asphalting of oil due to gas charging: This mechanism is often de-asphalten of oil column in reservoir due to gas charge into a crude oil. Zuo et al. (2012) proposed the gas charging mechanism for Tar mat formation include: (1)A late gas charge migrated into the reservoir moving to the top of the hydrocarbon column, (2) The gas spread down into the oil column very slowly over geologic time (increasing gas oil ratio(GOR) near the top of the column), which reduces the solubility of asphaltenes at the top of the column and forming colloid ally stable clusters, (3) Gravitational accumulation of the clusters toward the base of the column, (4) Finally, asphaltenes concentrated at the base to form a Tar mat.

This mechanism deemed the most probable in Zubair formation in Rumaila oil field.

Adsorption of asphaltenes onto clay minerals: kaolinite has a very high adsorption capacity for asphaltenes (Pernyeszi et al., 1998).Natural deasphalting due to adsorption onto kaolinite surfaces is an apparent mechanism (Sachsenhofer et al., 2006). This mechanism consider the most probable in the Zubair Formation as there is a strong relationship between Tar mat thickness and shale occurrence in most of the studied wells. This is indicated that the natural deasphalting due to adsorption onto clay mineral surfaces is probably responsible for precipitation of the Tar mat in sandstone of the Zubair reservoir. 


\section{CONCLusions}

Based on the rock core and cutting description as well as the study of the behavior of borehole logs including resistivity and NMR the Tar mat was found on the flanks of the North Rumaila oil field near the OWC. Thickness of Tar mat are determined in 33 wells in the eastern flank of the structure and found to be between $5.3 \mathrm{~m}$ to $13.2 \mathrm{~m}$ in R-169 and R-109, respectively. In western flank, the Tar mat thickness ranges 5.3 to $10.9 \mathrm{~m}$ in R-105 and R-095, respectively. Within the saddle area between the North and South Rumaila, Tar mat thickness was found to be $5.2 \mathrm{~m}$ (R-181 well). The thickness of the Tar mat layer increases in the northeastern part of the Rumaila oil field, and this is related to the increase of the volume of shale, where the Tar mat are intertwined and form a barrier between the oil column and the formation which impedes the process of secondary oil recovery.

The possible mechanism that forming the Tar mat within the Zubair Formation is the de-asphalting mechanism because of gas charge in the reservoir and the asphaltine adsorption onto the clay minerals (kaolinite).

\section{REFERENCE}

[1] Al-Ansari, R., (1993).The petroleum Geology of upper sandstone member of the Zubair Formation in the Rumaila South oilfield (Unpublished study), Dept. of reservoirs and fields development.Ministry of oil, Iraq.

[2] Alfayfi, A., Elmahdy, O., \& Amao, A. M. (2015).An Experimental Study for Enhancing the Recovery Factor of Tar Barrier Heterogeneous Reservoirs. Journal of Petroleum \& Environmental Biotechnology, $6(3), 1$.

[3] Almansour, A. O. (2014). Investigating and modeling tar-mats in a Kuwaiti carbonate reservoir and their role in understanding oil reserves and recovery economics.

[4] Al-Sakini, J.A. (1992). Summary of petroleum geology of Iraq and the Middle East. Northern Oil Company Press, Kirkuk, 179 p. (in Arabic).

[5] Asquith, G. and Krygowski D. (2004). AAPG Methods in Exploration, No. 16, Chapter 1: Basic Relationships of Well Log Interpretation. The American Association of Petroleum Geologists, Texas, USA. pp. 1-20.

[6] Azim, S. A., Al-Anzi, S., Hassan, Y. A., James, S. J., Mandal, D., \& Al-Ajmi, H. (2006). Identification, Origin and Distribution of Tarmats in Upper Zubair Sand Reservoir, Raudhatain Field, North Kuwait.In Abu Dhabi International Petroleum Exhibition and Conference. Society of Petroleum Engineers.

[7] Buday, T. (1980), The regional geology of Iraq. Vol. 1: Stratigraphy and Paleogeography. Publications of GEOSURV, Baghdad, $445 \mathrm{P}$.

[8] Connan J. (1984) Biodegradation of crude oils in reservoirs. In Advances in Petroleum Geochemistry (Edited by Brooks J. and Welte D.), Academic Press, London. Vol. 1, pp. 299-335.

[9] Dahl, B. and Speer, G. C. (1985). Organic geochemistry of the Oseberg Field (I) Petroleum Geochemistry in Exploration of the Norwegian Continental Shelf, Graham and Trotman, pp. 185-195.

[10] Head, I. M., Jones, D. M., Larter, S. R. (2003).Biological activity in the deep subsurface and the origin of heavy oil. Nature 426, pp. 344-352.

[11] Hirschberg, A. (1984). The role of asphaltenes in compositional grading of a reservoir's fluid column. Soc. Petroleum Eng. AIME, 13171

[12] Huc, A.Y., Nederlof, P., Debarre, R., Carpentier, B., Boussafir, M., Laggoun-Défarge, F., LenailChouteau, A., Bordas- Le Floch, N., (2000), Pyrobitumen occurrence and formation in a CambroOrdovician sandstone reservoir, Fahud salt basin, north Oman. Chemical Geology 168, pp. 99-112.

[13] Jacob, H., (1989). Classification, structure, genesis andpractical importance of natural solid oil bitumen("migrabitumen"). International Journal of Coal Geology11(1): pp. 65-79. https://doi.org/10.1016/ 0166-5162(89)90113-4

[14] Jassim, S.Z. and Goff, J.C., 2006. Geology of Iraq. Dolin, Prague and Moravian Museum, Brno, P. 431.

[15] Kennedy M. (2015), Practical Petrophysics, Developments in Petroleum Science Volume 62, MSK Scientific Consulting, pty ltd. Perth, Australia, P. 403.

[16] Kleinberg, R. L., \& Vinegar, H. J. (1996).NMR properties of reservoir fluids. The log analyst, 37(06), pp. 20-32.

[17] Larter, S.R., Bjørlykke, K.O., Karlsen, D.A., Nedkvitne, T., Eglinton, T.I., Johansen, P.E., Leythaeuser, D., Mason, P.C., Mitchell, A.W., Newcombe, G.A., (1990). Determination of Petroleum Accumulation Histories: Examples from the Ula field, Central Graben, Norwegian North Sea. In: Buller, A. (Ed.), North Sea oil and gas reservoirs: II. Graham and Trotman, London, pp. 319-330. 
Identification of Heavy Oil (Tar Mats) Deposits and Forming Mechanism in the Main Pay of the Zubair Formation in North Rumaila Oil Field, Southern Iraq

[18] Milner C. W. D., Rogers M. A. and Evans C. R. (1977), Petroleum transformations in reservoirs. J. Geochem. Explore 7, pp. 101-153.

[19] Montel, F. and Gouel, P.L. (1985).Prediction of compositional grading in a reservoir fluid column.Society of Petroleum Engineers, 14410.

[20] Nascimento, J. D. D., \& Gomes, R. M. (2004). Tar Mats Characterization From Nmr And Conventional Logs, Case Studies In Deepwater Reservoirs, Offshore Brazil. In SPWLA 45th Annual Logging Symposium. Society of Petrophysicists and Well-Log Analysts.

[21] Owen, R. M. S. and Nasr, S. N. (1958).Stratigraphy of the Kuwait - Basrah area.ln: L. G. Weeks (ed.): Habitat of oil: a symposium: AAPG, Tulsa, Oklahoma, P. $1252-1278$.

[22] Palmer S. E. (1984) Effect of water washing on $\mathrm{C}_{15+}$ hydrocarbon fraction of crude oils from northwest Palawan, Philippines. AAPG Bull. 68, pp 137-149.

[23] Pernyeszi, T., Patzko, A., Berkesi, O., De'kány, I. (1998).Asphaltene adsorption on clays and crude oil reservoir rocks. Colloids and Surfaces A: Physicochemical and Engineering Aspects 194, pp. 25-39.

[24] Poupon, A. andLeveaux, J. A. C. Q. U. E. S. (1971).Evaluation of water saturation in shaly formations.In SPWLA 12th annual logging symposium. Society of Petrophysicists and Well-Log Analysts, pp. 1-2.

[25] Sachsenhofer, R.F., Gratzer, R., Tschelaut, W., Bechtel, A. (2006). Characterisation of nonproducible oil in Eocene reservoir sandstones (Bad Hall Nord field, Alpine Foreland Basin, Austria). Marine and Petroleum Geology 23, pp. 1-15.

[26] Schlumberger (1989), eighth printing, Interpretation Log "Principles / applications", Sugar land, Texas 77478, P. 227

[27] Schlumberger (1997), Log interpretation of wireline Logs.

[28] Schlumberger copyright (2006),Nuclear Magnetic Resonance Imaging, 10 - NMR Porosity, pp. 1-31.

[29] Schulte, A.M. (1980). Compositional variations within a hydrocarbon column due to gravity. Soc. Petroleum Eng., AIME, pper no. 9235.

[30] Waples, D.W., (2000). The kinetics of in-reservoir oil destruction and gas formation: constraints from experimental and empirical data, and from thermodynamics. Organic Geochemistry 31, pp. 553-575.

[31] Wilhelms, A., \&Larter, S. R. (1995). Overview of the geochemistry of some tar mats from the North Sea and USA: Implications for tar-mat origin. Geological Society, London, Special Publications, 86(1), pp. 87101.

[32] Zuo, J. Y., Mullins, O. C., Mishra, V., Garcia, G., Dong, C., \& Zhang, D. (2012), Asphaltene grading and tar mats in oil reservoirs. Energy \& Fuels, 26 (3), 1670-1680.

Citation: Shaymaa Mohammed J., Amna M Handhal, (2019)'Identification of Heavy Oil (Tar Mats) Deposits and Forming Mechanism in the Main Pay of the Zubair Formation in North Rumaila Oil Field, Southern Iraq", Southeast Cameroon, International Journal of Mining Science (IJMS), 5(1), pp.1-10, DOI: http://dx.doi.org/10.20431/2454-9460.0501001

Copyright: (C) 2019 Authors. This is an open-access article distributed under the terms of the Creative Commons Attribution License, which permits unrestricted use, distribution, and reproduction in any medium, provided the original author and source are credited 